\title{
Experiences and Policy Suggestions on Poverty Alleviation through Territorial Development in Wumeng Mountain Area
}

\author{
Zhao Mei, Zhao Yaqiao, Li Xuekun, Zhou Lv, Wang Qi* \\ College of Economics and Management, Yunnan Agricultural University \\ Kunming 650201, Yunnan
}

\begin{abstract}
The purpose of this study is to summarize the experience of poverty alleviation through territorial development in Wumeng Mountain Area, and to provide policy recommendations for poverty alleviation through territorial development. This study uses normative analysis, empirical analysis and system analysis to analyze viewpoints. Through the research, three experiences of poverty alleviation through territorial development in Wumeng Mountain Area are obtained: (1) Improve the land productivity of poor peasant households through land development and poverty alleviation. (2) Promoting food security in poverty-stricken areas through territorial development and poverty alleviation. (3) Increasing the development resources of poor peasant households through land development and poverty alleviation. In view of the problems of poverty alleviation in Wumeng Mountain Area, three policies have been put forward: transforming the government's investment in territorial development into the policies of villagelevel organizations and peasant assets, guiding some land to poor peasant households, and guiding some land to poor peasant households.
\end{abstract}

Keywords-Wumeng Mountain Area; Poverty Alleviation through Territorial Development; Experiences; Policy Suggestions

\section{INTRODUCTION}

Wumeng Mountain Area is one of the 11 poverty-stricken areas in China. It spans 38 counties (cities and districts) adjacent to Sichuan, Guizhou and Yunnan provinces. It has a large number of poor people, a wide distribution and a high incidence of poverty. Centralized areas with special difficulties are the main battlefield for poverty alleviation in the new stage. Guided by the general idea of "promoting poverty alleviation and development by regional development and promoting regional development by poverty alleviation and development", a fixed-point contact mechanism has been established, with one or two ministries and commissions leading each area. The Ministry of Natural Resources, as the contact unit in Wumeng Mountain Area, is mainly responsible for "investigation and research, communication, supervision and guidance".

In recent years, the Ministry of Natural Resources has taken the work of poverty alleviation and development as a major political task and incorporated it into its key work layout. Land development has played an important role in promoting poverty alleviation and development in poverty-stricken areas,

Foundation Project: Public Welfare Industry Research Project of Ministry of Natural Resources (201511003)

First author: Zhao Mei (1978-), female, Wenshan native of Yunnan, lecturer, master of economics, research direction: agricultural economy.

Correspondent author: Wang Qi, female, associate professor, mainly engaged in agricultural economy research. and the work of poverty alleviation has achieved remarkable results.

\section{THE CONCEPT AND CONTENT OF POVERTY} ALLEVIATION THROUGH TERRITORIAL DEVELOPMENT

\section{A. The Concept of Poverty Alleviation through Territoria Development}

Territoria development is accompanied by the birth of mankind, in order to meet the economic reproduction and selfreproduction of human activities, land development is the core of territoria development. With the aggravation of human activities, especially with the over-use of natural resources in the process of human development, the constraints of natural resources are tightening. In order to coordinate the contradiction between protection and development, and to realize the sustainable development of human beings, territoria development has become the basis and constraints for the economic and social development of all countries.

Poverty alleviation through territoria development means that through the research, innovation and experiment of territoria development technology, the technology and method of territoria development technology poverty alleviation are formed, the land boundary between farmers is clarified, the productivity of land in poverty-stricken villages is improved, the value of land of poverty-stricken farmers is increased, and the land assets of poverty-stricken farmers are increased, so as to promote poverty. Farmers' ability of increasing production and income and sustainable development in agriculture promotes the transformation and upgrading of agricultural industry in poor areas, supplemented by the policy dividend of land and resources, and achieves the precise poverty alleviation of poor farmers in Wumeng Mountain Area.

\section{B. Contents of Poverty Alleviation through Territoria Development}

The specific contents of territoria development and poverty alleviation include: implementing land use index tilt to ensure economic development and land demand for poverty alleviation; carrying out comprehensive land consolidation to improve rural production, living and ecological environment; strengthening exploration and development of mineral 
resources and comprehensive utilization to promote the transformation of resource advantages; and effectively preventing and controlling geological disasters. Guarantee the safety of life and property of the poor people; guide the protection and exploitation of geological environment, promote the development and utilization of geological tourism resources; support the pilot work of land and resources management reform, provide strong policy support for economic development and poverty alleviation; implement two-way appointment exchanges among cadres to provide personnel support for poverty alleviation and fortification Bracing.

\section{MAJOR EXPERIENCE OF POVERTY ALLEVIATION THROUGH TERRITORIAL DEVELOPMENT IN WUMENG MOUNTAIN AREA}

\section{A. Improving the Land Productivity of Poor Farmers through Territoria Development and Poverty Alleviation}

At present, it is in an important period of rapid industrialization and urbanization, and also an important period of adjustment of land spatial structure. Through the development of land science and technology, Wumeng Mountain Area promotes the further optimization of spatial distribution and the continuous improvement of land productivity. In the process of territoria development, it not only meets the huge demand for land space for population increase, people's living improvement and economic development, but also protects arable land for food security, ecological security and people's health. According to the principles of balanced population, resources and environment, scientific spatial distribution of production space, living space and ecological space, and organic unification of economic, social and ecological benefits, we should control the intensity of development, adjust the spatial structure, and promote intensive and efficient production space, moderate living space and ecological space. The beautiful mountains and rivers leave more space for natural restoration and more fertile fields for agriculture.

Through geological environmental protection and development and utilization, the productivity of land in Wumeng Mountain Area is further improved. In view of the present situation of abundant geological relics and geological environment resources in Wumeng Mountain Area, according to local conditions, rational development and utilization of geological relics resources, declaration and construction of geological parks and mining parks are carried out, the geomorphological and ecological environment in Wumeng Mountain Area is effectively protected, the development and utilization of geological tourism resources in poor areas is promoted, and the development of tourism economy is promoted. The income of the impoverished people has been continuously increasing.

At the same time, in areas where conditions permit, the Wumeng Mountain Area have carried out pilot projects on the transfer of rural collective construction land, promoting the development and utilization of unused land such as the linkage between urban and rural construction land increase and decrease, low hills, gentle slopes and barren beaches, the reclamation of industrial and mining wasteland, and the restoration and management of mining environment, etc. The land productivity has been further improved and the poor people in Wumeng Mountains have been promoted. More benefits, get rid of poverty and get rich.

\section{B. Promoting Food Security in Poor Areas through Territoria Development and Poverty Alleviation}

The red line of cultivated land is the dam of food security. Protecting cultivated land is to protect food production. The 13th Five-Year Plan put forward that we should adhere to the strictest system of cultivated land protection and the red line of cultivated land. Only by guaranteeing the area and quantity of cultivated land can we talk about how to make use of cultivated land, increase grain production and keep and manage the world's grain warehouses.

In Wumeng Mountainou Area, strict farmland protection system is implemented, the balance of farmland occupation and compensation is well balanced according to law and regulations, the circulation of rural land is promoted in a standardized and orderly manner, the starting point and the end point are to safeguard, realize and develop farmers' rights and interests, and the three bottom points are to adhere to the nature of land public ownership unchanged, the red line of farmland is not broken through and the interests of farmers are not damaged. Line, on the basis of pilot projects in an orderly manner. Through improving the quality of cultivated land and land productivity, scientific land fallow and other measures of cultivated land protection and conservation, alternate and repeated fallow tillage, ultimately realize the sustainable utilization of cultivated land resources in the future, improve the quality of cultivated land and land productivity, and achieve stable and high yield of grain production. When food supply exceeds demand, rotation and fallow are used to reduce the amount of grain production. When food is scarce, these lands are quickly used to produce food. The overall balance of supply and demand of grain is maintained by increasing or decreasing cultivated land. Through the development of land science and technology, we can realize the grain storage and land use, and improve the food security level in povertystricken areas.

\section{Increasing the Development Resources of Poor Farmers through Territoria Development and Poverty Alleviation}

The Ministry of Natural Resources has incorporated all 38 counties (cities and districts) in Wumeng Mountain Area into demonstration counties of high-standard basic farmland construction, continuously increasing investment and carrying out comprehensive land consolidation. Supporting Wumeng District of Yunnan Province to carry out a major land consolidation project of "Promoting Land and Harmonizing Borders". Through comprehensive consolidation of Tianshui Road and Lin Village, the area of farmland has been increased, and the ecological environment, living conditions and rural areas of poor rural areas have been improved. 


\section{Policy Suggestions on Poverty AlleViation THROUGH TERRITORIAL DEVELOPMENT IN WUMENG MOUNTAIN AREA}

\section{A. Put forward the Policy of Transforming the Government's Investment Achievements in Territoria Development into the Assets of Village-level Organizations and Farmers.}

The policy of transforming the achievements of territoria development into the assets of village collective organizations and peasants will be promulgated, the income sources of collective economy will be expanded, the strength of collective economy will be strengthened, and the long-term assets income of poor peasant households will be increased.

For a long time, investment interritoria development has been from village to household, and the effect of pepper noodles on poverty alleviation is extremely insignificant. According to the national poverty alleviation plan, during the 13th Five-Year Plan period, it is necessary to break the "flood irrigation" form of poverty alleviation funds and innovate the poverty alleviation mode of assets income from financial support for agricultural projects. Under the premise of adhering to the basic rural economic system and the basic rural management system, this strategic deployment is to explore the use of natural resources, public assets, special financial poverty alleviation funds and other agricultural-related funds, as well as the rights and interests of peasant households, by steadily promoting the reform of the contractual management right of rural land and the use system of forest rights. With equity ownership, poor villages and poor households can obtain assets income from them, increase assets income of poor households, and explore a new path for precise poverty alleviation.

According to this strategic plan, we should formulate a policy of transforming the input results of territoria development into the assets of village collective organizations and farmers. Poverty alleviation through territoria development can be promoted by large-scale investment and the whole village. At the same time, farmers are required to share in each household and form mutual fund cooperatives. This will not only expand the income source of collective economy, strengthen the strength of collective economy, but also activate the enthusiasm of farmers to participate in cooperatives, and improve the long-term assets income of poor farmers.

\section{B. Promulgate Policies to Guide the Concentration of Some Land intoPoor Households}

Relevant land transfer policies have been issued to encourage some land to be concentrated in the hands of poor households with "lack of funds and technology, difficulties in going out to work and rich experience in agricultural production", to achieve the goal of increasing production and income by expanding the scale of operation, and gradually to cultivate these poor farmers into farmers of agricultural specialty or family farms. To achieve its goal of "taking agriculture as industry, increasing income from agriculture and developing agriculture".
According to the survey conducted by the Poverty Alleviation Office of the State Council, $76 \%$ of the poor peasant households without adequate food and clothing live in mountainous areas. $46 \%$ of the peasant households have less than $0.067 \mathrm{hm} 2$ of arable land per capita. Too little arable land is an important reason for the poverty of peasant households. In Wumeng Mountains, farmers with per capita arable land ranging from 0.5 to $1.5 \mathrm{mu}$ are the most common, accounting for more than half of the total number of farmers, and most of them are in poverty. Wumeng Mountain Area can reduce poverty by changing the allocation of farmers' land through policy guidance. Poor peasant households in Wumeng Mountain Area are the main force in the countryside. Most of them with knowledge, technology and wealth have moved out of the countryside, and a lot of land has been abandoned. For poor peasant households who are willing to farm and remain behind, they can concentrate part of their land in the hands of poor peasant households through guidance, subcontracting or relatives instead of farming, or village collectives with certain preferential measures, such as delimiting a certain area of land to poor peasant households for farming at rents below market prices. By expanding the scale of operation, we can achieve the goal of increasing production and income, gradually cultivate these poor farmers into potential farmers or farmers of family farms, the core members of new agricultural cooperatives and other roles, from blood transfusion poverty alleviation to selfhematopoiesis.

\section{Promulgate Policies to Reduce the Cost of Agricultural Land Management}

At present, the majority of the rural left-behind people in Wumeng Mountain Area have low educational level and old age. They generally lack funds, knowledge and skills, which is the real "hard bone" in the fight against poverty. If we want to extricate ourselves from poverty, we can only rely on employment assistance. As for the new type of operation subject, which is mainly engaged in labor-intensive industries such as primary processing of agricultural products, handicraft industry, processing and management of incoming materials, and has obvious benefits in lifting poor peasant households out of poverty, it is the carrier to increase the income of poor people and alleviate poverty through close employment and poverty alleviation. For enterprises, land is the most important factor of production, and it occupies a large proportion in the cost of production and operation. At present, the land supply in Wumeng Mountain Area is mostly to lease the land use right for several years to the land-use enterprises at one time, and the enterprises pay the transfer fee at one time. Compared with the annual rental system, the initial investment pressure of enterprises is increased, especially for small and medium-sized enterprises. From the government's point of view, this mode of land supply also has some problems, such as the government is difficult to control the land during the transfer period, and it is difficult to dispose of inefficient idle land. Therefore, the introduction of policies to reduce the cost of agricultural land management of enterprises will provide convenience for "poverty alleviation enterprises" to enter the countryside, and realize "one person employment, the whole family out of poverty", which is of great significance to fight against poverty and build a well-off society in an all-round way. 
In view of the rapid development of agricultural industrialization, broad prospects for further processing of agricultural products and the obvious benefits of poverty alleviation of poor farmers in Wumeng Mountain Area, land development projects should explore and support the establishment of logistics processing bases, such as logistics facilities and subsidies for factory building, or one-off construction of standardized and high-standard factory buildings. It shall be used by the new business entity for a fee. On the one hand, it can improve the quality and level of agricultural production, on the other hand, it can save the investment cost of new business entities, and at the same time, it can ensure the value-keeping and value-added of financial funds.

In order to optimize the development environment and reduce the operating cost of enterprises, preferential policies can be given in terms of land transfer price, land use mode and land transfer life. Considering the difficulty of one-time payment of resources price, enterprises can adopt the method of delaying payment of resources price. At the same time, according to the principle of land saving and intensive use, enterprises are encouraged to increase the land use rate and volume rate by means of storey-adding of factory buildings, transformation of factory areas, and internal land consolidation, on the premise that they conform to the planning and do not change their use, without increasing the land price.

\section{CONCLUSION}

Poverty alleviation in Wumeng Mountain Area has long been a common phenomenon of "poverty alleviation, poverty alleviation and poverty re-entry", and has not yet formed a long-term mechanism and policy guarantee of "poverty alleviation through territoria development". Land is the basis of people's survival. Only through the most basic territoria development and poverty alleviation can we solve the survival and development problems of this area. By summing up the experience of poverty alleviation through territoria development in Wumeng Mountain Area and putting forward corresponding policy guarantees, it can provide experience and reference for other regions in poverty alleviation through territoria development, and realize the goal of innovative mechanism and policy promotion and demonstration in the whole country.

\section{REFERENCES}

[1] Yuan Liang and Chen Meiqiu," Land consolidation and poverty alleviation" [J]. China's land and resources economy, 2017, (07): 24-25.

[2] Zeng Jianfa. "The prominent problems and Countermeasures in land expropriation and demolition" [J]. China's land and resources economy, 2017, (02):26-27.

[3] Zheng Zijing. "A study on the path of poverty alleviation through land use policy relocation in Wumeng Area: taking Xuyong County and Gulin County in Sichuan Province as examples "[J]. Land and Resources Information, 2016 (11): 52-56.

[4] Xun Guanyu. "An Analysis of the Poverty Alleviation Performance of Agricultural Industrialization in Wumeng District of Yunnan" [J]. Agricultural Resources and Regionalization of China, 2017 (01): 193 198.

[5] Gongji. "Research on Regional Development and Poverty Alleviation Programming in Several Poverty-stricken Areas "[M]. Beijing: People's Publishing House, 2013:29.

[6] Li Dongfa. "The Ministry of Land and Resources supports the path analysis of poverty alleviation in Wumeng Area" [J]. China's land and resources economy, 2014 (02): 32-35.

[7] "Exploration of rural land joint-stock cooperative system in the extremely poor areas of Liupanshui City, Guizhou Province" [J]. Journal of Guizhou Institute of Engineering and Technology, 2016 (06): 66-70. 